\title{
ETYKA ZAWODOWA W TURYSTYCE
}

\section{WSTĘP}

O podjęciu tytułowego problemu przesądzają między innymi następujące kwestie:

- złożoność motywów i form organizacyjnych turystyki,

- istota produktu turystycznego - dominują usługi, a nie dobra materialne, co stwarza istotną pokusę, szansę dla części przedsiębiorstw turystycznych na - określmy to eufemistycznie - nadużycie zaufania klienta,

- duża i rosnąca ranga turystyki w gospodarce,

- ingerencja państwa wydaje się konieczna dla wyrównania szans obydwu stron, rynku usług turystycznych, dokładniej - dla ochrony konsumenta, ale niesie też ryzyko nadmiernej regulacji.

W Polsce rynek usług turystycznych jest jeszcze w stadium „organizacji” w wielu wymiarach, temat zatem wydaje się szczególnie istotny. Kodeks Etyczny Turystyki zaproponowany przez Światową Organizację Turystki (WTO) w świadomości i praktyce polskiej branży turystycznej funkcjonuje w szczątkowym stopniu.

\section{TURYSTYKA W GOSPODARCE}

Istotnym argumentem na rzecz podjęcia tematu jest także rosnąca rola turystyki w gospodarce. Według WTTC (Worl Travel \& Tourism Council) gospodarka turystyczna wytworzy w 2009 roku w skali świata 9,4\% PKB, turystyka tworzy $7,6 \%$ miejsc pracy i stanowi $10,9 \%$ światowego eksportu ${ }^{1}$. 
W Polsce turystyka nie odgrywa jeszcze tak wielkiej roli w gospodarce, ale potencjał jest duży. W 2007 roku turyści zagraniczni zostawili u nas około 10,5 mld USD ${ }^{2}$. Według raportu „Rachunek satelitarny turystyki dla Polski 2005”3 konsumpcja turystyczna wyniosła w Polsce 37,2 mld złotych. Według szacunków autora w 2008 roku wartość tej konsumpcji osiągnęła wartość 51 miliardów złotych. Bardzo optymistycznie ocenia rangę turystyki w Polsce WTTC, stwierdzając, że wytworzy ona 7,7\% PKB, generując 7,2\% miejsc pracy w 2009 roku $^{4}$. Eączny popyt turystyczny, bezpośredni i pośredni, określa się w tym raporcie na ponad 150 miliardów złotych. O znaczeniu rynkowym turystyki świadczyć może także wielkość ruchu turystycznego. W 2008 roku mieszkańcy Polski odbyli ponad 45 milionów podroży, przeciętnie około 2,7 podróży na statystycznego, podróżującego Polaka.

Tabela 1. Uczestnictwo w ruchu turystycznym wg rodzajów wyjazdów. Liczba osób uczestniczących (w mln)

\begin{tabular}{|l|r|r|r|r|r|r|r|r|r|r|r|}
\hline Rodzaj podróży & 1997 & 1998 & 1999 & 2001 & 2002 & 2003 & 2004 & 2005 & 2006 & 2007 & 2008 \\
\hline Krajowe długookresowe & 11,2 & 11,4 & 11,2 & 10,1 & 10,4 & 10,0 & 9,0 & 9,3 & 8,9 & 9,1 & 9,5 \\
\hline Krajowe krótkookresowe & 13,0 & 11,9 & 13, & 10,6 & 10,9 & 9,7 & 8,6 & 7,5 & 7,5 & 7,5 & 6,6 \\
\hline Zagraniczne & 3,9 & 3,7 & 4,2 & 4,4 & 4,4 & 3,3 & 3,8 & 3,8 & 4,5 & 4,9 & 5,5 \\
\hline $\begin{array}{l}\text { Krajowe i zagraniczne } \\
\text { (ogółem) }\end{array}$ & 19,0 & 18,8 & 19,5 & 17,7 & 17,8 & 17,0 & 15,3 & 15,1 & 15,1 & 15,3 & 15,5 \\
\hline
\end{tabular}

Źródło: opracowanie własne na podstawie Krajowy ruch turystyczny, Instytut Turystyki, Warszawa 2002, 2009.

Liczba osób odwiedzających Polskę ulega wahaniom, ale 66 milionów to i tak dość dużo dodatkowych konsumentów dóbr i usług dla gospodarki.

$\mathrm{Z}$ danych zawartych $\mathrm{w}$ tabeli 1 widać, jak istotnym wahaniom podlegają podróże Polaków, różnica między skrajnymi latami 1999 i 2005 sięga 4,4 miliona osób. Mając na uwadze przeciętną wielkość wydatków jednego podróżnego - w 2008 roku - było to 940 zł przy podróżach długich i 340 zł przy podróżach krótkich, w 2005 roku było to odpowiednio 570 i 220 złotych - otrzymujemy kilkanaście miliardów złotych różnicy w rocznych wielkościach popytu. Uwzględniając złożoność produktu turystycznego i fakt, że wartość mnożnika turystycznego wynosi w Polsce około 2,5, otrzymujemy kwoty popytu rynkowego bardzo znaczące dla całej gospodarki. Analizując przyczyny tych zmian, być może trzeba

\footnotetext{
${ }^{2}$ Instytut Turystyki, Warszawa, http://www.intur.com.pl (24.05.2009).

${ }^{3}$ Ministerstwo Sportu i Turystyki, http://msport.gov.pl/prace-badawcze-turystyka.

${ }^{4}$ TRAVEL \& TOURISM ECONOMIC IMPACT, WTTC 2009.
} 
wziąć pod uwagę potrzebę ingerencji państwa w różnych obszarach powstawania i realizacji popytu turystycznego.

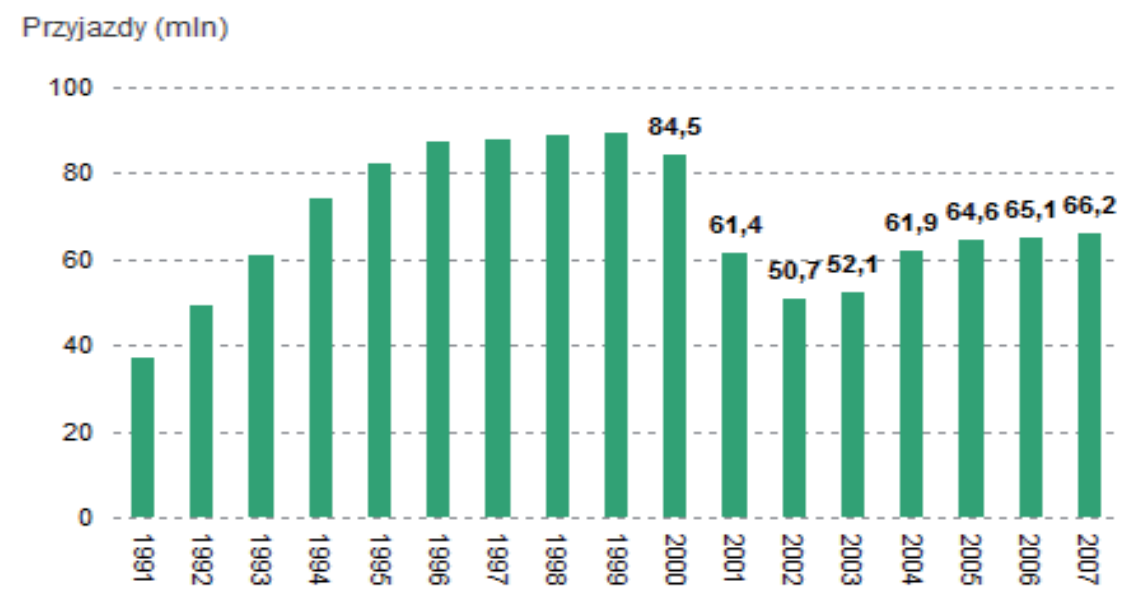

Wykres 1. Przyjazdy cudzoziemców do Polski ogółem (mln przekroczeń granicy)

Źródło: Przyjazdy do Polski, Instytut Turystyki, Warszawa 2009.

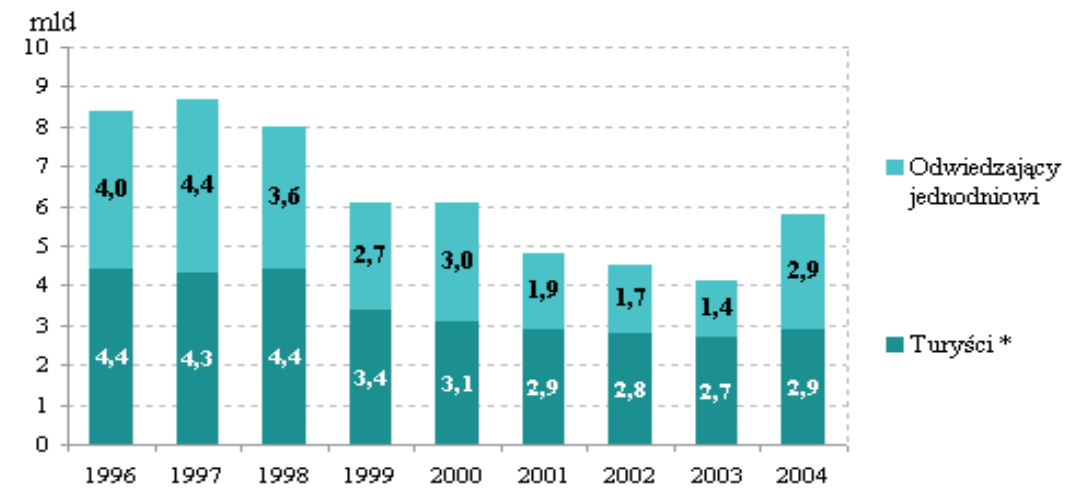

Wykres 2. Łączne przychody dewizowe w latach 1996-2004 (w mld USD) Źródło: Instytut Turystyki, Warszawa 2009.

W najlepszym dla siebie okresie Polska była 7(!) krajem na świecie pod względem liczby przyjętych turystów, posiadając 3,2\% udziału w całej światowej recepcji turystycznej. Mając na uwadze deficyt w handlu zagranicznym, „eksport” usług turystycznych jest znaczącą pozycją w bilansie handlowym. Wpływów na poziomie 8,7 (1997 r.) - 10,6 miliardów dolarów (2007 r.) nie można bagatelizować. Jak widać $\mathrm{z}$ wykresu 2 i tabeli 2, różnice między skrajnymi latami sięgają 6 
miliardów USD. Miliardów, których nie zarobili przedsiębiorcy, pracownicy i budżety. Zatem być może odpowiednia ingerencja państwa choćby poprzez nakłady na marketing zagraniczny czy odpowiednią organizację przejść granicznych może się przyczynić do istotnego wzrostu eksportu turystycznego.

Tablela 2. Wpływy dewizowe Polski z turystyki przyjazdowej w latach 1996-2006 (w mld USD)

\begin{tabular}{|l|c|c|c|}
\hline & PRZYCHOdY OGółEM & W TYM: TURYŚCI & $\begin{array}{c}\text { OdWIEDZAJACY JEDNO- } \\
\text { DNIOWI }\end{array}$ \\
\hline 1996 & 8,400 & 4,400 & 4,000 \\
\hline 1997 & 8,700 & 4,300 & 4,400 \\
\hline 1998 & 8,000 & 4,400 & 3,600 \\
\hline 1999 & 6,100 & 3,400 & 2,700 \\
\hline 2000 & 6,100 & 3,100 & 3,000 \\
\hline 2001 & 4,800 & 2,900 & 1,900 \\
\hline 2002 & 4,490 & 2,800 & 1,690 \\
\hline 2003 & 4,070 & 2,690 & 1,380 \\
\hline 2004 & 5,785 & 2,900 & 2,885 \\
\hline 2005 & 6,230 & 3,330 & 2,900 \\
\hline 2006 & 7,187 & 3,447 & 3,740 \\
\hline 2007 & 10,573 & 4,834 & 5,73 \\
\hline
\end{tabular}

Źródło: Instytut Turystyki, Warszawa 2009.

\section{WŁAŚCIWOŚCI PRODUKTU TURYSTYCZNEGO}

Niewielka część produktu (produktów) turystycznych ma charakter materialny. Istotą produktu turystycznego jest usługa. Składają się na to między innymi: usługi noclegowe, gastronomiczne, przewodnickie, ubezpieczeniowe, usługi zwiedzania, usługi informacyjne etc. Istotą usług, w tym turystycznych, jest ich niematerialność. Usług nie można magazynować, ich „produkcja” - świadczenie odbywa się jednocześnie $\mathrm{z}$ konsumpcją . Turysta usługobiorca musi się pojawić w miejscu konsumpcji - hotelu, restauracji, na wydarzeniu kulturalnym czy w atrakcji turystycznej, jak muzeum, park rozrywki itd. Usługi turystycznej nie można popróbować, a w razie niezadowolenia oddać jak pralkę czy telewizor. Niesie to za sobą duże ryzyko przede wszystkim dla konsumenta. Nie mając możliwości empirycznej weryfikacji nabywanego produktu, gra on w specyficzną rosyjską ruletkę. Albo zakupiona usługa jest zgodna $\mathrm{z}$ jego oczekiwaniami i/oraz zawartą ze sprzedawcą umową, albo nie jest zgodna. Klasyczne dobra możemy w takiej sytuacji, przy

${ }^{5}$ J. Kaczmarek (red.), Produkt turystyczny, PWE, Warszawa 2005, s. 72 i nast. 
zachowaniu odpowiednich reguł, oddać sprzedawcy. W turystyce tej możliwości nie mamy.

Nie możemy oddać niezgodnej z programem, umową wycieczki, nie możemy jej „popróbować”, a potem kupić. Dodatkowo, usługa wykonywana jest w określonym środowisku: społecznym, przyrodniczym, politycznym etc., środowisku zmiennym niezależnym $\mathrm{w}$ pewnym stopniu od organizatora. Cechą rynkową usług turystycznych jest przesunięcie w czasie konsumpcji i samego kupna - zapłaty, niekiedy o kilka miesięcy.

\section{CHARAKTERYSTYKA RYNKÓW USŁUG TURYSTYCZNYCH}

Okres gospodarki socjalistycznej w turystyce, podobnie jak i w innych sferach gospodarki, charakteryzował się rynkiem producenta. Państwo de facto było monopolistą w znakomitej części rynku usług turystycznych. Chociaż oprócz przedsiębiorstw w nazwie "państwowych" istniały jeszcze przedsiębiorstwa w nazwie „regionalne” czy podmioty związków i zrzeszeń, faktycznie funkcjonowały one jak podmioty będące własnością państwa. Taki stan rzeczy „obowiązywał” w odniesieniu do sprzedaży wyjazdów zagranicznych, usług hotelowych i wielu innych noclegowych, usług transportowych. W nieco mniejszym stopniu zmonopolizowane były usługi przewodnickie i pilockie, a także od pewnego momentu usługi wymiany walut. Transformacja systemowa przyniosła w początkowym okresie duże zróżnicowanie rynku, pojawienie się wielu „drobnych” podmiotów. $\mathrm{Z}$ upływem lat rynek zaczął się ponownie monopolizować, choć tym razem jako własność prywatna. $Z$ przejawem faktycznej monopolizacji mamy do czynienia w sektorze biur podróży. Oficjalnie istnieje w Polsce prawie 3000 biur podróży, ale około $80 \%$ ich działalności to pośrednictwo. Wymienić by można kilka wielkich europejskich biur, których ofertę sprzedaje znakomita część biur funkcjonujących w Polsce. W wyższym segmencie hoteli można by wymienić kilka sieci, które „opanowały” polski rynek. Taka monopolistyczna sytuacja istotnie przyczynia się do zachowań nieetycznych.

\section{ETYKA W TURYSTYCE}

Przyjmując szerokie rozumienie etyki, jako nauki filozoficznej o normach moralnych, normach, które rozstrzygają, co jest dobre, a co jest złe, z zespołem nakazów, wynikających $\mathrm{z}$ norm moralnych ${ }^{6}$, możemy odnieść to zagadnienie lub

\footnotetext{
6 J. M. Bocheński, Podręcznik mądrości tego świata, „Philed”, Kraków 1994, s. 74.
} 
(wartościując) musimy również do turystyki. Złożoność tej formy aktywności społeczno-gospodarczej, jaką jest turystyka, sprawia, że problem etyki, zachowań etycznych pojawia się we wszystkich jej aspektach.

Jednym z pierwszych odniesień etyki w stosunku do turystyki jest zapewne filozofia ekologiczna - ekofilozofia ${ }^{7}$.Turystyka jako forma aktywności przestrzennej w sposób oczywisty wykorzystuje środowisko naturalne. Wykorzystanie może przybierać różne przejawy - od budowy infrastruktury turystycznej, np.: hotele, wyciagi narciarskie, drogi, po zadeptywanie natury - w dosłownym znaczeniu, czy „podrzucanie” wszelkiego rodzaju „turystycznych” śmieci. Stwierdzić zatem można, że kwestie etyki w turystyce dotyczą zarówno strony podażowej, jak i popytowej. Po stronie popytowej można by wymienić etyczne przesłanki i konsekwencje tak zwanej seksturystyki, różnych odmian safari i wiele innych.

Poprzez etykę zawodową w turystyce rozumieć będziemy te zagadnienia, zachowania, normy, które wynikają przede wszystkim z zachowań, intencji podmiotów funkcjonujących po stronie podaży turystycznej.

Potencjalne obszary zachowań nieetycznych tkwią między innymi w:

- informacji o miejscu docelowym i jakości - standardzie świadczeń,

- niepełnym, niezgodnym z umową wykonaniu usługi,

- nierówności stron umowy - asymetria ryzyka,

- „bilet w jedną stronę”.

Wspomniana wcześniej specyfika usług turystycznych, jednoczesność „wytwarzania" i konsumpcji, rozerwanie w czasie aktów zakupu i konsumpcji, brak możliwości przetestowania - sprawiają, że istnieje możliwość niezgodności faktycznego produktu w stosunku do deklarowanego.

W odniesieniu do bazy noclegowej rozbieżności mogą dotyczyć między innymi standardu formalnego, położenia obiektu czy usytuowania samego pokoju. Często turysta w miejscu docelowym dowiaduje się, że z ,jakichś” powodów zakwaterowany będzie w obiekcie o niższym standardzie niż wynika to z umowy. Jest to swoiste „postawienie pod ścianą”, turysta, skoro już się znalazł w miejscu wypoczynku, niekiedy wiele kilometrów od domu, nie ma wyboru, musi przyjąć te gorsze warunki. Ewentualna rekompensata po powrocie nie zrekompensuje poniesionego dyskomfortu. $Z$ podobną sytuacją mamy do czynienia, gdy faktyczne położenie obiektu noclegowego jest inne niż deklarowane w momencie zakupu. Odległość od plaży, wyciągu narciarskiego ma istotne znaczenie dla przyjemności korzystania z tych urządzeń. Może być też tak, że odległość jest zgodna, ale hotel od plaży dzieli ruchliwa szosa. Obok pensjonatu może być usytuowana uciążliwa fabryka, oczyszczalnia ścieków czy inna „atrakcja” uprzykrzająca wypoczynek. Po-

\footnotetext{
${ }^{7}$ S. Jojczyk, Filozofia i elementy etyki w turystyce, WSTiH, Gdańsk 2009, s. 101-102.
} 
kój może być z przysłowiowym widokiem na morze albo na parking lub zaplecze magazynowe hotelu.

W odniesieniu do bazy gastronomicznej istotnym „niedoinformowaniem” może być kwestia godzin wydawania posiłków, samoobsługi lub obsługi kelnerskiej, dostępności posiłków wegetariańskich czy fakt, że sala konsumpcyjna nie znajduje się w budynku, w którym śpimy.

Czysta, piaszczysta i niezatłoczona plaża albo kamienista, mała i brudna - to klasyczny przypadek różnic między informacją z biura a rzeczywistością.

Oferowane turyście atrakcje, usługi uzupełniające odbiegają często in minus od uzgodnionych lub sugerowanych w momencie zakupu. Przyczyny niezgodności mogą mieć trojakie źródło. Po pierwsze - świadome wprowadzenie turysty w błąd, świadome błędne przedstawienie miejsca docelowego lub świadome przemilczenie negatywnych okoliczności. Ten przypadek uznać trzeba za szczególnie nieetyczny. Jest to postawa, którą opisać można stwierdzeniem: „byle sprzedać, a potem [...] może turysta nie będzie miał sił dochodzić swoich praw”. Po drugie - niestaranne sprawdzenie miejsca docelowego, nieegzekwowanie warunków przez pośrednika od bezpośredniego usługodawcy. Ten stan rzeczy wynikać może z braku profesjonalnego przygotowania pośrednika, z pozycji monopolistycznej usługodawcy. Po trzecie - niezgodność może być konsekwencją faktu, że w turystyce, pewnym stopniu sprzedaje się marzenia, wyobrażenie o miejscu docelowym i jego atrakcjach. Część turystów będzie zachwycona Wenecją, jej urokiem i będzie się cieszyć ze zwiadzenia, inna część turystów stwierdzi, że kanały brzydko pachną i wyjedzie zawiedziona.

Można wyodrębnić jeszcze jeden powód niezgodności, będący konsekwencją rozwoju technik multimedialnych i działań marketingowych. Te techniki pozwalają, a działania marketingowe często w tym kierunku zmierzają, na "upiększanie" rzeczywistości. Jej wizualizację w praktycznie dowolnie atrakcyjnej postaci. A sporadyczność aktywności turystycznej turysty i nieznajomość miejsca docelowego (co jest zrozumiałe) stwarzają ogromne możliwości „przekoloryzowania”, co ostatecznie też oznacza wprowadzenie turysty w błąd.

Nierówności stron umowy - asymetria ryzyka. Ten obszar nieetycznych postaw biznesu ma swoje podłoże w regulacjach prawnych i strukturach rynkowych (co po części się pokrywa).

Pierwszym powodem nierówności jest fakt, że sytuacja w wielu segmentach rynku usług turystycznych ma cechy rynku monopolistycznego. Drugim powodem są regulacje prawne, w tym Ustawa o usługach turystycznych $z$ dnia 29 sierpnia 1997 roku która, była, jak na polskie warunki nowoczesna w chwili wprowadzenia. Dzisiaj jest zdecydowanie niedostateczna. Regulacje tej ustawy albo z powodu luk, albo braku precyzji stwarzają biurom turystycznym i innym podmiotom możliwość nieetyczneego zachowywania się wobec klienta turysty. 
Klasycznym przykładem jest zawieranie umowy, która obciąża turystę dużymi kosztami rezygnacji z udziału w wycieczce (w skrajnym przypadku 100\%), bez faktycznie jakichkolwiek kosztów dla biura - rekompensaty wobec turysty, gdy impreza nie dochodzi do skutku $z$ winy biura lub organizatora. Łatwość instytucjonalna przedsiębiorstw turystycznych dochodzenia swoich roszczeń wobec turysty wiąże się z brakiem form instytucjonalnych ochrony jego interesów. Brak efektywnego udostępnienia turyście informacji o obowiązkach stron w przypadku usługi noclegowej czy gastronomicznej sprawia, że turyści zazwyczaj nie mają wiedzy i świadomości o koniecznym zakresie świadczeń i przysługujących im prawach.

Rekompensowanie braków w standardzie wyposażenia pokoju niższą ceną lub innymi usługami jest w Polsce absolutną rzadkością. Procedury egzekwowania zawartej umowy są dla klienta zbyt złożone i kosztowne, zazwyczaj kończy się to rezygnacją ze strony turysty.

Częstym powodem zachowań nieetycznych wobec klienta jest sytuacja ekonomiczna biur lub innych świadczeniodawców. Sytuacja niezaplanowanej i niezamierzonej niewypłacalności, ale też często świadomych działań polegających na zawieraniu umów mimo wiedzy o braku możliwości ich realizacji. Kłopoty z powrotem turystów z wakacji na skutek niewypłacalności biura są „normą” wakacyjnego krajobrazu Polski.

\section{ZAKOŃCZENIE}

Przyjmując za punkt wyjścia stwierdzenie, że istniejący stan w turystyce potencjalnie i faktycznie sprzyja zachowaniom nieetycznym oraz że ta sytuacja jest niewłaściwa między innymi:

- dla konsumentów,

- dla tej części branży turystycznej, która prowadzi biznes w sposób etyczny wobec klienta i kontrahentów,

- dla tworzenia zaufania do branży turystycznej,

- dla rozwoju ekonomicznego i wzrostu udziału turystyki w gospodarce,

- dla przeciwdziałania ucieczce turystów z Polski do regionów o wyższej etyce branży,

konieczne jest podjęcie określonych działań. Wyodrębnić można kilka obszarów sfer tych działań:

- polityka turystyczna państwa polegająca na zwiększonej funkcji regulacyjnej przymusowe ubezpieczenia, gwarancje finansowe itp. organizatorów turystyki;

- skuteczniejsza, szybsza reakcja władz nadzorujących działalność biur i innych podmiotów (obecnie procesy roszczeniowe w urzędach marszałkowskich toczą się latami); 
- efektywniejsze działanie władz regionalnych na rzecz egzekwowania istniejących regulacji - np. nadużywanie nazw obiektów noclegowych w sposób wprowadzający w błąd klienta co do oczekiwanego standardu (np. hotel hotelik);

- działania branży turystycznej dla propagowania i egzekwowania wobec działających w niej podmiotów kodeksu etycznego w turystyce; Polska Izba Turystyczna i inne tego typu podmioty wydają się właściwym forum działań w tym zakresie.

Kolejny sposób na zmianę sytuacji to zmiana świadomości klientów co do praw w sferze usług turystycznych i możliwości ich egzekwowania. Tutaj jest pole do działania organizacji konsumenckich, ale także do intensyfikacji działań informacyjnych Urzędu Ochrony Konkurencji i Konsumentów. Urząd podejmuje wiele istotnych działań, których efekty nie są powszechnie znane.

Wreszcie działania z obszaru CSR (społecznej odpowiedzialności biznesu) są szansą na zmianę sytuacji na lepszą, aby turystyka nie tylko przynosiła korzyści ekonomiczne, ale była też fenomenem kulturowo-społecznym ${ }^{8}$.

\section{OCCUPATIONAL ETHICS IN TOURISM}

SUMMARY

Occupational ethics is very important in all professions, in every kind of business activity. In tourism the ethics'problem is seems to be important and complicated. In tourism we have concern first and foremost with service, it means lack of opportunities to verify what we pay for. Secondly as a rule buy act and consumption act are distant in time. In concern to very important part of services (holiday departures and other) consumption takes place far to the place of buy. Among other things this circumstances make a temptation "give" chance to dishonest tourism businessmen, consciously initating tourist into a mistake. Factually sale other "product" than was declared. Existing institutional solutions - formal-like tourism services law, model contract concerned rendering services, lots of branch associations activity - not conductive to improve the situation. Situation , which is currently in Poland considerably stray away from in minus in relation to formal regulation and consciousness of tourism industry in $15 \mathrm{EU}$ countries.

In thet fact seems to be necessary the government influence in order to protect tourist consumer businesses in present days, and also perspectively build customs of "good business" in a tourism branch. It seems to be so fundamental that meaning of tourism economy is growing, also growing as well danger of competitive seizure the polish tourists by more ethical working markets.

\footnotetext{
${ }^{8}$ S. Owsianowska, Turystyka jako fenomen kulturowo-spoteczny, [w:] Z. Dziubiński (red.), Aksjologia turystyki, Salezjańska Organizacja Sportowa Rzeczypospolitej Polskiej, Warszawa 2006.
} 
